\title{
Mulching of Ornamental Trees: Effects on Growth and Physiology
}

\author{
Francesco Ferrini, Alessio Fini, Piero Frangi, and Gabriele Amoroso
}

\begin{abstract}
Two organic mulching materials applied to newly planted Tilia $\times$ europaea and Aesculus $\times$ carnea trees were evaluated for effects on tree growth and physiology. Both mulches were efficient in maintaining a cleared area around newly planted trees, although pine bark was more durable than coarse compost from mixed green material. Trees mulched with compost generally had greater height, trunk diameter, and current-year shoot growth. Differences were more evident in the first year in Aesculus and in the second year in Tilia. Mulching with compost increased carbon assimilation of linden leaves in 2005 when compared with pine bark and chemical weeding. Both mulching materials increased transpiration of horsechestnut in 2005. Little effect on gas exchange was found in 2006 in both species. However, because mulched trees were larger with longer shoots, whole plant leaf gas exchange was probably greater. Mulching had very limited effects on chlorophyll fluorescence. Results of this project have shown that mulching materials applied around trees after planting can positively affect tree growth without significantly affecting tree physiology.
\end{abstract}

Key Words. Aesculus $\times$ carnea; chlorophyll fluorescence; compost; leaf gas exchange; mulching; pine bark; Tilia $\times$ europaea

A key to success for new tree planting both in open-field nurseries and in the urban environment is the protection of young plants from noncrop plant species (including some hardwoods, shrubs, grasses, and forbs). These fast-growing plants often kill or greatly suppress desired trees by competing with them for light, water, and nutrients needed to grow. As a result, nurserymen, arborists, and urban forest managers generally use herbicides to suppress noncrop vegetation.

However, the European Union's Fifth Environmental Action Program (5EAP) set out a series of targets for the year 2000, including "the significant reduction in pesticide use per unit of land under production, and the conversion to methods of integrated pest control."

As a consequence, to protect young trees, environmentally sound, effective, cost-efficient, and socially acceptable techniques for managing noncrop vegetation are needed.

In this scenario, we focused on the need for environmentally friendly establishment and low-cost management methods of the urban green areas. Mulching and its skilled use can contribute to such a development by improving organic matter content in the soils and by affecting other soil characteristics (Harris et al. 2004).

Even if mulching is a worldwide practice in urban green areas and different materials can be used for this purpose (mainly shredded wood, chipped woods, pine bark, and, above all, composted materials) (Rakow 1989), little research has been done in Italy to determine the effectiveness of this practice.

Positive effects after organic mulch application have been obtained by previous research, which has shown beneficial effects on soil physical and chemical properties (Fraedrich and Ham 1982; Litzow and Pellett 1983; Watson 1988; Appleton et al. 1990; Himelick and Watson 1990; Smith and Rakow 1992; Iles and Dosmann 1999; Tiquina et al. 2007; Dahiya et al. 2007) and on plant growth and physiology (Watson 1988; Green and Watson 1989; Appleton et al. 1990; Himelick and Watson 1990). Also, the invertebrate diversity can be positively affected by mulching (Jordan and Jones 2007). However, sometimes the results from mulching are variable being affected by the different environmental conditions and by the different tree species (Whitcomb 1979; Iles and Dosmann 1999). Moreover, if the quality of the mulching materials supplied by the producers is not satisfactory, tree performances can be affected in a negative way. This can be related either to its quality or to its misuse, i.e., adding too much material, which can negatively affect soil oxygen content (Gilman and Grabosky 2004; Hanslin et al. 2005), although Watson and Kupkowski (1991) found no detrimental effect from the application of $0.45 \mathrm{~m}(1.5 \mathrm{ft})$ of wood chip mulch over the soil in which the roots of trees were growing. The application of bark mulch can sometimes decrease growth in the first year, but the effect on plant growth is positive when examined in the long term (Samyn and de Vos 2002). This can be caused by a temporary nitrogen depression until the microorganisms are able to decompose a sufficient amount of organic material to provide the needed nitrogen (Craul 1992).

Composted materials need to be well characterized for nutrient values, stability, and other properties for the support of tree growth and effect against weeds. In a review of the use of composts for mulching and soil amendments, Sæbø and Ferrini (2006) suggest designing the composts to fit the specific effects that are wanted. For example, composts for mulching should consist of layers of compost of different particle sizes so that both nutrients can be supplied and weeds are not given good germination conditions.

The purpose of this study was to investigate the use of mulching materials and their possible influence on growth and physiology of two shade tree species widely grown in the urban environment.

\section{MATERIALS AND METHODS}

\section{Plant Material}

In 2004, before bud break, uniform, 2.5 to $3 \mathrm{~m}$ tall ( 8.3 to $9.9 \mathrm{ft}$ ),

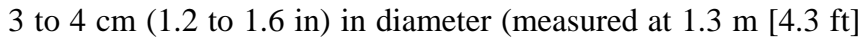


height), balled and burlapped (size of the root ball was approximately $30 \mathrm{~cm}$ [12 in] in diameter) Aesculus $\times$ carnea (red horsechestnut) and Tilia $\times$ europaea (european linden) trees were planted in an experimental plot located at the Fondazione Minoprio (Como) $\left(45^{\circ} 44^{\prime} \mathrm{N}, 9^{\circ} 04^{\prime} \mathrm{E}\right)$. Planting holes were two times the width and one-and-a-half times the depth of the root ball to ensure a greater volume of loose soil within the planting hole. The sides of the planting pit were scarified with a shovel. Before planting, some soil mixed with peat (50\% in volume) was placed at the bottom of the planting hole. At planting, care was taken that the root flare was not positioned below the soil level. All trees with almost identical size characteristics were obtained from the same nursery and planted at the same time.

Trees were planted in a randomized block design with three blocks and four plants per block (12 plants per each treatment, 36 plants per species) and provided supplemental irrigation. Treatments included:

- Mulching with coarse compost derived from green material left after sifting (coarse compost) (layer 5 to $8 \mathrm{~cm} \mathrm{[2} \mathrm{to} 3$ in]);

- Mulching with pine bark (layer 5 to $8 \mathrm{~cm}$ [2 to 3 in]); and

- Control (weeding by herbicide).

In 2004, no data were collected with the exception of plant height and trunk diameter at the end of the growing season. In 2005 and 2006, the following parameters were measured:

1) Plant height and trunk diameter (determined on each plant at the end of each growing season; plant diameter was also measured in 2007);

2) Shoot length (determined on 20 shoots/plant at the end of the growing season; shoot length was also measured in 2007);

3) Leaf gas exchange (instantaneous net photosynthesis [Pn], transpiration rate [E], water use efficiency [WUE, calculated by dividing Pn by E], stomatal conductance [ $g s]$, and internal $\mathrm{CO}_{2}$ concentration [ci]; measured eight times in 2005 and five times in 2006); and

4) Chlorophyll fluorescence (measured four times in 2005 and three times in 2006).

Leaf gas exchange was measured during the whole growing season using the CIRAS-2 portable infrared gas analyzer (PP Systems, Hertfordshire, U.K.). The readings were taken between
8:00 A.M. and 1:00 P.M., which was presumed to be the diurnal period when photosynthetic rates would be maximal, in sunny days under fixed $\mathrm{CO}_{2}$ concentration $(360 \mathrm{ppm})$ and saturating irradiance $\left(1300 \mu \mathrm{mol} / \mathrm{m}^{-2} / \mathrm{s}^{-1}\right.$ provided by a built-in red lightemitting diode radiation source) on six plant per each thesis on five fully expanded leaves from the outer part of the crown and at different heights per plant per treatment. Chlorophyll fluorescence was measured on the same plants by using a HandyPEA portable fluorescence spectrometer (Hansatech Instruments Ltd., King's Lynn, U.K.) four times from mid-May through the end of July (Percival 2005). Fluorescence values were obtained by placing leaves in darkness for $30 \mathrm{~min}$ by attaching light-exclusion clips to the leaf surface of whole trees. Upon the application of a saturating flash $\left(3,000 \mu \mathrm{mol} / \mathrm{m}^{-2} / \mathrm{s}^{-1}\right.$ for $\left.1 \mathrm{sec}\right)$, fluorescence raises from the ground state value (Fo) to its maximum value, Fm. In this condition, QA, the first electron acceptor of photosystem II (PSII), is fully reduced. This allows the determination of the maximal or potential photochemical efficiency or optimal quantum yield of PSII given by $\mathrm{Fv} / \mathrm{Fm}=(\mathrm{Fm}-\mathrm{Fo}) / \mathrm{Fm}$ where $\mathrm{Fm}$ is the maximum value. Fv/Fm is considered a quantitative measure of the maximal or potential photochemical efficiency or optimal quantum yield of PSII. In healthy leaves, this value is always above 0.75 to 0.8 , independent of the plant species studied. A lower value indicates that a proportion of PSII reaction centers are damaged, a phenomenon called photoinhibition, often observed in plants under stress conditions (Maxwell and Johnson 2000; Krause and Weis 1991; Percival 2005; Lazár 2006).

\section{Statistical Analyses}

All data were subjected to one-way analysis of variance using SPSS statistical package for Windows (SPSS Inc., Chicago, IL, U.S.). Difference between means of investigated parameters were tested with Duncan's multiple range test $(P \leq 0.05)$. Data on leaf gas exchange and on chlorophyll fluorescence have been processed per single sampling date, merged together, and processed again to obtain the average value on an annual basis.

\section{RESULTS AND DISCUSSION}

Tables 1 and 2 summarize growth data for both species. In horsechestnut, height increment was higher in trees mulched with compost only in the first year, whereas no difference emerged either in the second year or considering the total height increment (Table 1). Similarly, trunk diameter was positively

Table 1. Effect of soil management techniques on and plant height $(\mathrm{cm})$, trunk diameter (cm), and shoot length of Aesculus $\times$ carnea. $^{\mathrm{z}}$

\begin{tabular}{|c|c|c|c|c|c|}
\hline Parameter & Year & Pine bark & Compost & Control & $P$ \\
\hline \multirow{2}{*}{ Height increment $(\mathrm{cm})$} & 2004-2005 & $3.28 \mathrm{ab}$ & $5.76 \mathrm{a}$ & $1.54 \mathrm{~b}$ & $*$ \\
\hline & 2005-2006 & 32.95 & 38.81 & 33.75 & NS \\
\hline Total height increment $(\mathrm{cm})$ & 2004-2006 & 36.23 & 44.57 & 35.29 & NS \\
\hline \multirow[t]{3}{*}{ Diameter increment (mm) } & 2004-2005 & $11.89 \mathrm{~b}$ & $18.11 \mathrm{a}$ & $12.69 \mathrm{~b}$ & $*$ \\
\hline & 2005-2006 & 15.23 & 17.24 & 16.3 & NS \\
\hline & 2006-2007 & 14.45 & 15.81 & 13.91 & NS \\
\hline Total diameter increment (mm) & 2004-2007 & $41.57 \mathrm{~b}$ & $51.16 \mathrm{a}$ & $42.9 \mathrm{~b}$ & $* *$ \\
\hline \multirow[t]{3}{*}{ Shoot length $(\mathrm{cm})$} & 2005 & $9.57 \mathrm{~b}$ & $13.94 \mathrm{a}$ & $13.72 \mathrm{a}$ & $* *$ \\
\hline & 2006 & 47.37 & 46.98 & 45.34 & NS \\
\hline & 2007 & $54.72 \mathrm{~b}$ & $62.6 \mathrm{a}$ & $55.34 \mathrm{~b}$ & $* *$ \\
\hline
\end{tabular}

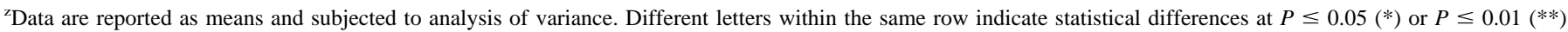
using Duncan test.

$\mathrm{NS}=$ nonsignificant. 
Table 2. Effect of soil management techniques on and plant height $(\mathrm{cm})$, trunk diameter $(\mathrm{cm})$, and shoot length of Tilia $\times$ europaea. $^{z}$

\begin{tabular}{|c|c|c|c|c|c|}
\hline Parameter & Year & Pine bark & Compost & Control & $P$ \\
\hline \multirow[t]{2}{*}{ Height increment $(\mathrm{cm})$} & 2004-2005 & 12.5 & 20 & 11.11 & NS \\
\hline & 2005-2006 & $67.61 \mathrm{ab}$ & $77.83 \mathrm{a}$ & $51.08 \mathrm{~b}$ & $* *$ \\
\hline Total height increment $(\mathrm{cm})$ & 2004-2006 & 80.11 & 97.83 & 62.19 & NS \\
\hline \multirow[t]{3}{*}{ Diameter increment $(\mathrm{mm})$} & 2004-2005 & $9.5 \mathrm{ab}$ & $8.73 \mathrm{~b}$ & $10.41 \mathrm{a}$ & $*$ \\
\hline & 2005-2006 & $16.3 \mathrm{~b}$ & $19.17 \mathrm{a}$ & $14.09 \mathrm{~b}$ & $* *$ \\
\hline & 2006-2007 & 17.04 & 18.17 & 16.39 & NS \\
\hline Total diameter increment (mm) & 2004-2007 & $42.84 \mathrm{~b}$ & $46.07 \mathrm{a}$ & $40.89 \mathrm{~b}$ & $*$ \\
\hline \multirow[t]{3}{*}{ Shoot length $(\mathrm{cm})$} & 2005 & $20.02 \mathrm{~b}$ & $25.97 \mathrm{a}$ & $18.14 \mathrm{~b}$ & $* *$ \\
\hline & 2006 & $75.45 \mathrm{~b}$ & $83.57 \mathrm{a}$ & $58.83 \mathrm{c}$ & $* *$ \\
\hline & 2007 & $82.94 \mathrm{a}$ & $79.8 \mathrm{a}$ & $63.67 \mathrm{~b}$ & $* *$ \\
\hline
\end{tabular}

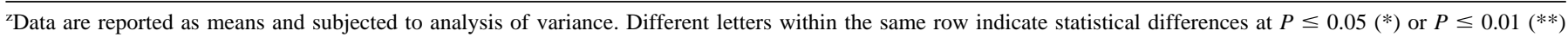
using Duncan test.

$\mathrm{NS}=$ nonsignificant.

affected by compost mulching in the first year compared with pine bark and control trees. This parameter was also higher considering the total increment after 3 years from planting. Shoot length was generally higher in trees mulched with compost.

In linden trees, the effects of mulching were more evident in the second year after planting when trees mulched with compost generally showed higher values of the parameters measured than control trees (Table 2). Total diameter increment was higher in trees mulched with compost, whereas plant height was not statistically affected.

In 2005, coarse compost was more effective to increase mean annual net photosynthesis of Tilia $\times$ europaea than pine bark and control. On Aesculus $\times$ carnea, no statistical differences were found among the different management techniques (Table 3). However, because mulched trees were larger with longer shoots, whole-plant leaf gas exchange was probably greater.

Mulching with both compost and pine bark increased transpiration of horsechestnut in 2005 compared with chemical weeding, whereas no effect was found in 2006. No differences were found on Tilia $\times$ europaea in both years for this parameter (Table 4).

Net photosynthesis also showed a declining trend over time in both species in 2005, whereas this trend was not observed in 2006. An explanation for this behavior is the higher rainfall during August in 2006 than in 2005. Differences were only noted in linden at the beginning and at the end of the growing season, when control trees showed lower Pn values compared with those mulched with compost (Figure 1). No differences were found in horsechestnut (Figure 2). Comparing the findings of the 2 separated years, the Pn for horsechestnut trees was higher in 2006, probably as a result of the different environmental conditions. In this regard, it needs to be stressed that individual leaf photosynthesis has demonstrated high variability compared with whole plant gas exchange, and it is sometimes complicated by a poor relationship of dry matter production to yield (Klingemann et al. 2005), but it is the only way to measure leaf gas exchange in adult trees.

Water use efficiency, in this research considered as the ratio of carbon gain during $\mathrm{CO}_{2}$ assimilation $\left(\mathrm{A}, \mu \mathrm{mol} / \mathrm{m}^{-2} / \mathrm{s}^{-1}\right.$ ) to water loss during transpiration $\left(\mathrm{E}, \mathrm{mmol} / \mathrm{m}^{-2} / \mathrm{s}^{-1}\right)$, is of major importance to the survival, productivity, and fitness of individual plants and it was higher in control trees only in 2005 in Tilia and in 2006 in Aesculus. Actually, the two species showed different patterns in the 2 years. Tilia $\times$ europaea had higher $\mathrm{Pn}$ and E values in 2005 compared with Aesculus $\times$ carnea, which in 2006 showed higher values of photosynthesis but not a corresponding increase in transpiration, which was actually lower. As a consequence, this species showed higher values of WUE.

Table 3. Net photosynthesis (A), transpiration (E), water use efficiency (WUE), stomatal conductance (Gs), substomatal $\mathrm{CO}_{2}$ concentration $(\mathrm{Ci})$, and chlorophyll fluorescence values in Aesculus $\times$ carnea young trees under different cultivation techniques. ${ }^{2}$

\begin{tabular}{|c|c|c|c|c|c|}
\hline Parameter & Year & Pine bark & Compost & Control & $P$ \\
\hline \multirow[t]{2}{*}{$\mathrm{A}\left(\mu \mathrm{mol} / \mathrm{m}^{-2} / \mathrm{s}^{-1}\right)$} & 2005 & 6.75 & 6.91 & 6.95 & NS \\
\hline & 2006 & 8.43 & 8.85 & 8.53 & NS \\
\hline \multirow[t]{2}{*}{$\mathrm{E}\left(\mathrm{mmol} / \mathrm{m}^{-2} / \mathrm{s}^{-1}\right)$} & 2005 & $2.66 \mathrm{a}$ & $2.81 \mathrm{a}$ & $2.46 \mathrm{~b}$ & $* *$ \\
\hline & 2006 & 1.76 & 1.96 & 1.78 & NS \\
\hline \multirow[t]{2}{*}{ WUE (A/E) } & 2005 & $2.65 \mathrm{ab}$ & $2.56 \mathrm{~b}$ & $2.93 \mathrm{a}$ & $*$ \\
\hline & 2006 & 5.60 & 5.04 & 5.11 & NS \\
\hline \multirow[t]{2}{*}{ Gs $\left(\mathrm{mmol} / \mathrm{m}^{-2} / \mathrm{s}^{-1}\right)$} & 2005 & $149.01 \mathrm{a}$ & $148.11 \mathrm{a}$ & 124.85 & $* *$ \\
\hline & 2006 & 98.84 & 107.05 & 101.02 & NS \\
\hline \multirow[t]{2}{*}{$\mathrm{Ci}(\mathrm{ppm})$} & 2005 & 178.06 & 171.75 & 160.58 & NS \\
\hline & 2006 & 181.95 & 190.00 & 192.26 & NS \\
\hline \multirow[t]{2}{*}{ Chlorophyll fluorescence (Fv/Fm) } & 2005 & 0.75 & 0.74 & 0.73 & NS \\
\hline & 2006 & 0.75 & 0.74 & 0.74 & NS \\
\hline
\end{tabular}

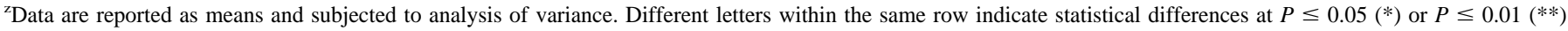
using Duncan test.

NS = nonsignificant. 
Table 4. Net photosynthesis (A), transpiration (E), water use efficiency (WUE), stomatal conductance (Gs), Substomatal $\mathrm{CO}_{2}$ concentration (Ci), and chlorophyll fluorescence values in Tilia $\times$ europaea young trees under different cultivation techniques. ${ }^{2}$

\begin{tabular}{|c|c|c|c|c|c|}
\hline Parameter & Year & Pine bark & Compost & Control & $P$ \\
\hline \multirow[t]{2}{*}{$\mathrm{A}\left(\mu \mathrm{mol} / \mathrm{m}^{-2} / \mathrm{s}^{-1}\right)$} & 2005 & $8.65 \mathrm{~b}$ & $9.65 \mathrm{a}$ & $8.88 \mathrm{~b}$ & $* *$ \\
\hline & 2006 & 7.63 & 7.93 & 7.67 & NS \\
\hline \multirow[t]{2}{*}{$\mathrm{E}\left(\mathrm{mmol} / \mathrm{m}^{-2} / \mathrm{s}^{-1}\right)$} & 2005 & 3.18 & 3.32 & 3.23 & NS \\
\hline & 2006 & 1.84 & 1.75 & 1.69 & NS \\
\hline \multirow[t]{2}{*}{ WUE (A/E) } & 2005 & 2.90 & 3.11 & 2.88 & NS \\
\hline & 2006 & $4.32 \mathrm{~b}$ & $4.9 \mathrm{ab}$ & $5.06 \mathrm{a}$ & $*$ \\
\hline \multirow[t]{2}{*}{ Gs $\left(\mathrm{mmol} / \mathrm{m}^{-2} / \mathrm{s}^{-1}\right)$} & 2005 & $187.65 \mathrm{~b}$ & $199.54 \mathrm{a}$ & $186.78 \mathrm{~b}$ & $*$ \\
\hline & 2006 & $111.67 \mathrm{a}$ & $108.59 \mathrm{a}$ & $97.46 \mathrm{~b}$ & $*$ \\
\hline \multirow[t]{2}{*}{$\mathrm{Ci}(\mathrm{ppm})$} & 2005 & 178.63 & 169.89 & 175.01 & NS \\
\hline & 2006 & $223.2 \mathrm{a}$ & $214.37 \mathrm{a}$ & $202.37 \mathrm{~b}$ & $* *$ \\
\hline \multirow[t]{2}{*}{ Chlorophyll fluorescence (Fv/Fm) } & 2005 & 0.76 & 0.75 & 0.77 & NS \\
\hline & 2006 & 0.77 & 0.77 & 0.74 & NS \\
\hline
\end{tabular}

${ }^{\mathrm{z}}$ Data are reported as means and subjected to analysis of variance. Different letters within the same row indicate statistical differences at $P \leq 0.05(*)$ or $P \leq 0.01(* *)$ using Duncan test.

$\mathrm{NS}=$ nonsignificant.

It has been generally demonstrated that increased WUE can be a water conservation measure indicating that more carbon can be accumulated for growth with the use of less water (Nilsen and Orcutt 1996; Jones 2004).

Stomatal conductance (Gs) was higher in trees mulched with compost in both species and it showed superior values in 2005 than 2006. The relation of WUE and Gs clearly indicates that these two variables are, in this case, inversely correlated. A decrease in stomatal conductance causes a proportionally larger decrease in transpiration than in carbon assimilation, with the net result being a higher WUE.

In this regard, it also has to be underlined that instantaneous WUE refers to a comparison of $\mathrm{CO}_{2}$ assimilated versus $\mathrm{H}_{2} \mathrm{O}$ transpired by individual leaves (or canopies) and is affected by environmental and genetic factors (Glenn et al. 2006) and it also varies among years considered (Fageria et al. 2006). Therefore, studies of instantaneous WUE by gas exchange techniques are difficult in field situations because environmental conditions around the leaves are always changing and it is hard to determine an average plant WUE (Nilsen and Orcutt 1996). Also, differ-

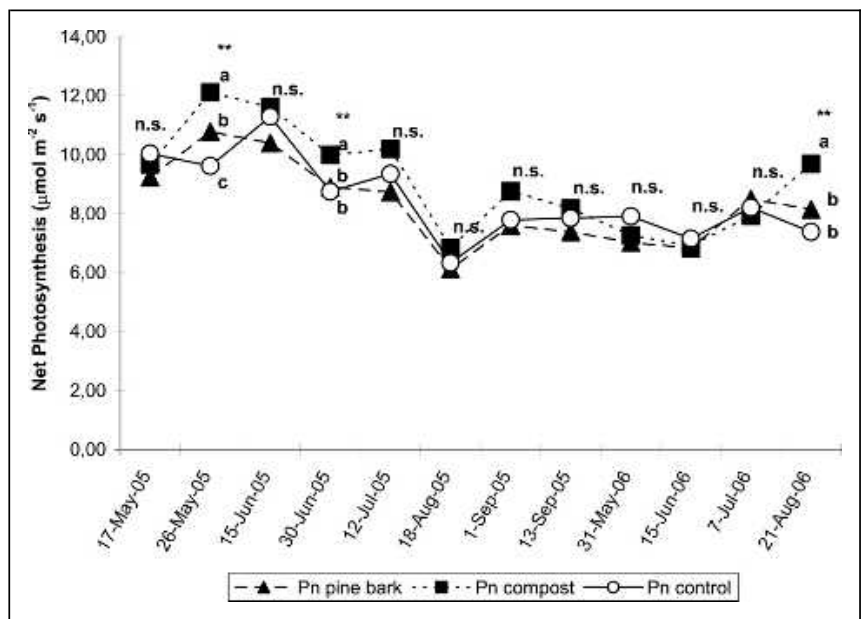

Figure 1. Net photosinthesis $\left(\mu \mathrm{mol} / \mathrm{m}^{-2} / \mathrm{s}^{-1}\right)$ in Tilia $\times$ europaea young trees under different cultivation techniques. Different letters indicate statistically differences at $P<0.05$ using Duncan test. ences in WUE determined at the leaf level may be reduced substantially at the canopy level (Lambers et al. 1998), and it can be finally hypothesized that, being mulched trees bigger and with longer shoots, they would be expected to have a higher leaf gas exchange on a whole plant basis.

Leaf internal $\mathrm{CO}_{2}$ concentration was not affected in both species in 2005, whereas it was higher in mulched Tilia trees in the second year and, in general, showed superior values in 2006.

Photochemical efficiencies of PSII $(\mathrm{Fv} / \mathrm{Fm})$ of the two species, measured during both growing seasons from June to September, were similar on an annual basis, and their values were comprised between 0.74 and 0.77 (Tables 1 and 2). No differences emerged among the different treatments, even when considering the single sampling date, except for the last measurements in 2006 on Aesculus, when mulched trees showed higher values. The highest Fv/Fm values were observed in July and were 0.8 on average among the treatments (data not shown).

\section{CONCLUSION}

Mulching significantly promoted growth of red horsechestnut and european linden trees and had limited influence on leaf gas

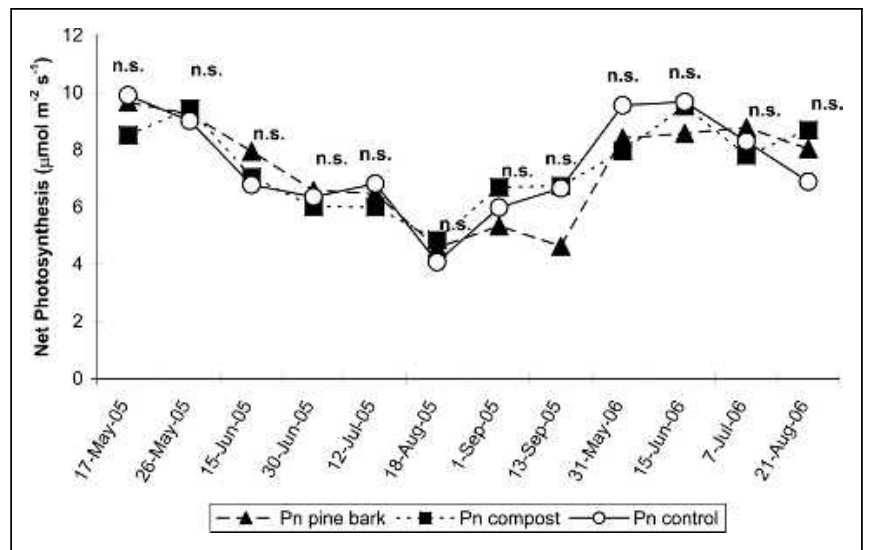

Figure 2. Net photosinthesis $\left(\mu \mathrm{mol} / \mathrm{m}^{-2} / \mathrm{s}^{-1}\right)$ in Aesculus $\times$ carnea young trees under different cultivation techniques. Different letters indicate statistically differences at $P<0.05$ using Duncan test. 
exchange and on internal fluorescence features of PSII. Therefore, we recommend application of mulching material obtained from composted wood chips and shredded wood to improve growth performance of the two species tested. Furthermore, as stated by Harris et al. (2004), several of the benefits, including improvements in soil structure, quality, and plant health, are accrued over time and are difficult to measure in short-term experiments.

In the 2 different years, some differences in physiological behavior were found between the two species; thus, further research is needed into the effect of different mulching materials in different species on leaf gas exchange as well as on soil characteristics, which can affect plant physiology.

Acknowledgments. We thank Regione Lombardia Project "Progetto di Sperimentazione Regionale sul Florovivaismo Tecniche eco-compatibili di gestione del vivaismo e del verde ornamentale" (TECOGEST). Support for this project also came in part from the Regione Toscana (Italy) inside the research project "Research on multipurpose green areas" (RISVEM).

\section{LITERATURE CITED}

Appleton, B.L., J.F. Derr, and B.B. Ross. 1990. The effect of various landscape weed control measures on soil moisture and temperature, and tree root growth. Journal of Arboriculture 16:264-268.

Craul, P.J. 1992. Urban Soil in Landscape Design. John Wiley and Sons, Inc., New York.

Dahiya, R., J. Ingwersen, and T. Streck. 2007. The effect of mulching and tillage on water and temperature regimes of a loess soil: Experimental findings and modeling. Soil and Tillage Research 96:52-63.

Fageria, N.K., V.C. Baligar, and R.B. Clark. 2006. Physiology of Crop Production. Food Product Press, Inc., Binghamton, NY. 345 pp.

Fraedrich, S.W., and D.L. Ham. 1982. Wood chip mulching around maples: Effect on tree growth and soil characteristics. Journal of Arboriculture 8:85-89.

Gilman, E.F., and J. Grabosky. 2004. Mulch and planting depth affect live oak (Quercus virginiana Mill.) establishment. Journal of Arboriculture 30:311-317.

Glenn, D.M., R. Scorza, and W.R. Okie. 2006. Genetic and environmental effects on water use efficiency in peach. Journal of the American Society for Horticultural Science 131:290-294.

Green, T.L., and G.W. Watson. 1989. Effects of turfgrass and mulch on the establishment and growth of bare root sugar maples. Journal of Arboriculture 15:268-271.

Hanslin, H.M., A. Sæbø, and O. Bergersen. 2005. Estimation of oxygen concentration in the soil gas phase beneath compost mulch by means of a simple method. Urban Forestry and Urban Greening 4:37-40.

Harris, R.W., J.R. Clark, and N.P. Matheny. 2004 Arboriculture. 4th ed. Prentice Hall Inc., Upper Saddle River, NJ.

Himelick, E.B., and G.W. Watson. 1990. Reduction of oak chlorosis with wood chip mulch treatments. Journal of Arboriculture 16: 275-278.

Iles, J.K., and M.S. Dosmann. 1999. Effect of organic and mineral mulches on soil properties and growth of fairview flame red maple trees. Journal of Arboriculture 25:163-167.

Jones, H. 2004. What is water use efficiency? pp. 27-40. In: Bacon, M.A. (Ed.). Water Use Efficiency in Plant Biology. CRC Press, Boca Raton, FL.

Jordan, K.K., and S.C. Jones. 2007. Invertebrate diversity in newly established mulch habitats in a midwestern urban landscape. Urban Ecosystems 10:87-95.

Klingemann, W.E., M.W. van Iersel, J.G. Kang, R.M. Augé, J.L. Moore, and P.C. Flanagan. 2005. Whole-plant gas exchange measurements of mycorrhizal 'Iceberg' roses exposed to cyclic drought. Crop Protection (Guildford, Surrey) 24:309-317.
Krause, G.H., and E. Weis. 1991. Chlorophyll fluorescence and photosynthesis: The basics. Annual Review of Plant Physiology and Plant Molecular Biology 42:313-349.

Lambers, H., F. Stuart Chapin III, and T.L. Pons. 1998. Plant Physiological Ecology. Springer-Verlag New York Inc., New York. 540 pp.

Lazár, D. 2006. The polyphasic chlorophyll a fluorescence rise measured under high intensity of exciting light. Functional Plant Biology 33:9-30.

Litzow, M., and H. Pellett. 1983. Influence of mulch materials on growth of green ash. Journal of Arboriculture 9:7-11.

Maxwell, K., and G.N. Johnson. 2000. Chlorophyll fluorescence-A practical guide. Journal of Experimental Botany 51:659-668.

Nilsen, E.T., and O.M. Orcutt. 1996. Physiology of Plants Under Stress: Abiotic Factors. John Wiley \& Sons, Inc., New York. 689 pp.

Percival, G.C. 2005. The use of chlorophyll fluorescence to identify chemical and environmental stress in leaf tissue of three oak (Quercus) species. Journal of Arboriculture 31:215-227.

Rakow, D.A. 1989. The Types and Uses of Mulches in the Landscape. Cornell Coop. Ext. Fact Sheet. p. 700.10.

Sæb $\varnothing$, A., and F. Ferrini. 2006. The use of compost in urban green areas-A review for practical application. Urban Forestry and Urban Greening 4:159-169.

Samyn, J., and B. de Vos. 2002. The assessment of mulch sheets to inhibit competitive vegetation in tree plantations in urban and natural environment. Urban Forestry and Urban Greening 1:25-37.

Smith, A.M., and D.A. Rakow. 1992. Strategies for reducing water input in woody landscape plantings. Journal of Arboriculture 18:165-170.

Tiquina, S.M., J. Lloyd, D.A. Herms, H.A.J. Hoitink, and F.C. Michel Jr. 2007. Effects of mulching on soil nutrients, microbial activity and rhizosphere bacterial community structure determined by analysis of TRFLPs of PCR-amplified rRNA genes. Applied Soil Ecology 21: $31-48$.

Watson, G.W. 1988. Organic mulch and grass competition influence tree root development. Journal of Arboriculture 14:200-203.

Watson, G.W., and G. Kupkowski. 1991. Effects of a deep layer of mulch on the soil environment and tree root growth. Journal of Arboriculture 17:242-245.

Whitcomb, C.E. 1979. Factors affecting the establishment of urban trees. Journal of Arboriculture 5:217-219.

Francesco Ferrini (corresponding author)

Dipartimento di Ortoflorofrutticoltura

viale delle Idee 30

Sesto Fiorentino (FI), 50019 Italy

francesco.ferrini@unifi.it

Alessio Fini

Dipartimento di Ortoflorofrutticoltura

viale delle Idee 30

Sesto Fiorentino (FI), 50019 Italy

alessio.fini@unifi.it

Piero Frangi

Fondazione Minoprio

Centro Mirt

viale Raimondi 54

Vertemate con Minoprio (CO), 22070 Italy

frangi@fondazioneminoprio.it

Gabriele Amoroso

Fondazione Minoprio

Centro Mirt

viale Raimondi 54

Vertemate con Minoprio (CO), 22070 Italy

g.amoroso@fondazioneminoprio.it 
Résumé. Deux matériaux organiques servant de paillis, et qui ont été appliqués sur des Tilia $\times$ europaea et des Aesculus $\times$ carnea, ont été évalués en fonction de leurs effets sur la croissance et la physiologie des arbres. Les deux paillis étaient efficaces pour maintenir une surface propre autour des arbres nouvellement plantés, et ce même si le paillis d'écorces de pin était plus durable que le compost grossier provenant d'un mélange de matériaux verts. Les arbres avec un paillis de compost avaient généralement une hauteur, un diamètre de tronc et un taux de croissance annuel qui étaient supérieurs. Les différences étaient plus évidentes la première année avec Aesculus $\times$ carnea et la seconde année avec Tilia $\times$ europaea. Le paillis de compost augmentait l'assimilation en carbone chez les feuilles du tilleul en 2005, et ce si on comparait avec le paillis d'écorce de pin et le désherbage mécanique. Les deux paillis augmentaient la transpiration chez le marronnier en 2005. Peu d'effets ont été observés en regard des échanges gazeux pour les deux espèces en 2006. Quoiqu'il en soit, du fait que les arbres avec paillis avaient de plus longues pousses annuelles, l'échange foliaire gazeux global de la plante était probablement plus élevé. Le paillis avait des effets limités sur la fluorescence de la chlorophylle.

Zusammenfassung. Zwei organische Mulchmaterialien, die zur Pflanzng von Tilia x europea und Aesculus x carnea verwendet wurden, wurden bezüglich ihres Einflusses auf Wachstum und Physiologie bewertet. Beide Mulchmaterialien sorgten für eine saubere Fläche um die neu gepflanzten Bäume, aber die Kiefernrinde hielt länger als der grobe Kompost aus gemischten Grünabfällen. Mit Kompost gemuchte Bäume hatten allgemein eine größere Höhe, Stammdurchmesser und Trieb- wachstum. Die Unterschiede waren bei Aesculus im ersten Jahr, bei Tilia im zweiten Jahr sichtbar. Kompostmulch verstärkte die Kohlenstoffassimilation der Lindenblätter in 2005, verglichen zu Kiefernrinde und chemischer Unkrautbekämpfung. Beide Mulchmaterialien erhöhten die Transpiration von Kastanien in 2005. In 2006 wurden bei beiden Spezies nur kleine Effekte beim Gasaustausch gemessen. Trotzdem war der gesamte Blattgasaustausch wahrscheinlich größer, weil die gemulchten Bäume längere Triebe hatten. Mulchen hatte nur einen geringen Einfluss auf die Chlorophyllfluoreszenz.

Resumen. Se evaluaron dos materiales orgánicos de mulching aplicados a árboles recién plantados de Tilia x europaea y Aesculus x carnea para conocer los efectos en el crecimiento y fisiología. Ambos mulches fueron eficientes en mantener un área libre alrededor de los árboles, aunque la corteza de pino fue más durable que la composta gruesa de materiales verdes mezclados. Los árboles mulcheados con composta generalmente tuvieron mayor altura, diámetro del tronco y crecimiento corriente anual del tallo. Las diferencias fueron más evidentes en el primer año en Aesculus y en el segundo año en Tilia. El mulching con composta incrementó la asimilación de carbono de hojas de tilo en 2005, al comparar con corteza de pino y desmalezadores químicos. Ambos materiales del mulching incrementaron la transpiración del castaño en 2005. Se encontró poco efecto en intercambio de gases en 2006 en ambas especies. Sin embargo, debido a que los árboles mulcheados fueron más grandes con brotes más largos, el intercambio gaseoso de toda la planta fue probablemente más grande. El mulching tuvo efectos muy limitados en la fluorescencia de clorofila. 